\title{
DAYA DUKUNG SPASIAL KAWASAN PERTAMBAKAN \\ MELALUI INTERPRETASI CITRA SATELIT ALOS AVNIR-2 \\ STUDI KASUS KABUPATEN MAROS SULAWESI SELATAN
}

\section{THE SPATIAL CARRYING CAPACITY OF AQUACULTURE AREA THROUGH THE SATELLITE IMAGERY INTERPRETATION OF ALOS AVNIR-2 CASE IN MAROS DISTRICT SOUTH SULAWESI PROVINCE}

\author{
Syahrial Nur Amri dan Taslim Arifin \\ Pusat Riset Kelautan, Badan Riset dan Sumberdaya Manusia \\ Kementerian Kelautan dan Perikanan \\ Kompleks Bina samudera Jl. Pasir Putih 1 Ancol Timur Lt. 4 Jakarta 14430 \\ Telp. (021) 64700755 Fax. (021) 64711654 \\ e-mail: sn_amri@yahoo.co.id \\ Diterima tanggal: 18 Januari 2018 ; diterima setelah perbaikan: 26 Maret 2018 ; Disetujui tanggal: 27 Maret 2018 \\ DOI: http://dx.doi.org/10.15578/jkn.v1i1.6473
}

\begin{abstract}
ABSTRAK
Perhitungan daya dukung kawasan pertambakan penting dilakukan untuk mengoptimalkan pemanfaatan kawasan pesisir. Perhitungan daya dukung spasial membutuhkan ketersediaan data spasial yang akurat, dan salah satu penyedia data spasial yang terbaik saat ini adalah melalui pemanfaatan citra satelit. Penelitian ini bertujuan untuk mengetahui kemampuan lahan pertambakan dalam mendukung aktifitas masyarakat pesisir dan pembangunan daerah. Penelitian ini meliputi dua tahapan, yaitu 1) mengidentifikasi secara spasial luasan kawasan tambak melalui interpretasi citra satelit ALOS AVNIR-2 dengan teknik masking citra, 2) menghitung nilai Carrying Capacity Ratio (CCR) untuk mengetahui kemampuan lahan terhadap aktifitas masyarakat pesisir. Hasil interpretasi citra ALOS AVNIR-2 menunjukkan luasan tambak di Kabupaten Maros yang teridentifikasi sebesar 9.621,60 hektar, dan analisis CCR menunjukkan nilai sebesar 2,79 atau >1. Nilai tersebut mengindikasikan kemampuan lahan tambak yang relatif masih mampu memenuhi kebutuhan aktifitas masyarakatnya. Kecamatan Bontoa merupakan wilayah dengan nilai CCR terendah $(1,73)$, yang berarti bahwa lahan tambak yang tersedia sudah hampir tidak mampu mendukung sepenuhnya aktifitas masyarakat. Dibutuhkan strategi pengelolaan berupa peningkatan produktivitas melalui pola intensifikasi, dan atau menekan petumbuhan penduduk.
\end{abstract}

Kata kunci: Daya dukung spasial, kawasan pertambakan, interpretasi citra, ALOS-AVNIR-2, Maros Sulawesi Selatan.

\section{ABSTRACT}

Calculation of carrying capacity of aquaculture area is important to optimize the coastal area utilization. The calculations of the spatial carrying capacity require the availability of accurate spatial data, and one of the best spatial data providers today is through the use of satellite imagery. This study aims to determine the ability of the pond land in support of the coastal community activities and regional development. This research covers two stages: 1) spatially identifies the pond area through the interpretation of ALOS AVNIR-2 satellite imagery with the masking technique; 2) Calculating the value of Carrying Capacity Ratio (CCR) to understand the ability of land to coastal community activities. The results show that the pond areas in Maros District identified as 9.621,60 hectares, and the CCR analysis shows a value of 2,79 or $>1$. The value indicates the ability of pond land which is still relatively able to fulfil the needs of community activities. Bontoa sub-district is the region with the lowest CCR value (1,73), which means that the available of pond land is almost unable to fully support the community's activities. Management strategies are needed in the form of increased productivity through the intensification patterns, and / or suppressing the population growth.

Keywords: Spatial carrying capacity, aquaculture area, imagery interpretation, ALOS-AVNIR-2, Maros Sulawesi Selatan.

Daya Dukung Spasial Kawasan Pertambakan Melalui Interpretasi Citra Satelit Alos Avnir-2 Studi Kasus Kabupaten Maros Sulawesi Selatan 


\section{PENDAHULUAN}

Indonesia merupakan produsen ikan terbesar kedua di dunia setelah China, dengan perikanan tangkap dan produksi akuakultur, termasuk tanaman air, diperkirakan pada 6,5 dan 14,4 juta ton, masing-masing pada tahun 2014 (Tran et al., 2017). Luas areal tambak di Indonesia saat ini sekitar 667.083 atau sekitar 22,5 $\%$ dari potensi lahan yang tersedia yakni seluas 2.964.331 hektar yang tersebar di seluruh Indonesia (Pusat Data, Statistik, dan Informasi KKP, 2015). Area tambak tersebut didominasi oleh budi daya udang dan bandeng, dimana dalam kurun waktu 4 tahun, produksi perikanan budi daya udang mengalami peningkatan rata-rata $15,82 \%$ dan komoditi bandeng rata-rata 10,84\% dari tahun 2010-2014 (Pusat Data, Statistik, dan Informasi KKP, 2015). Saat ini, Pemerintah Indonesia terus mendorong pertumbuhan industri udang untuk memastikan ketahanan pangan (Gusmawati et al., 2017). Pemerintah Indonesia menargetkan produksi udang dalam dekade berikutnya dari $0,3-0,4$ juta ton menjadi $0,6-1,0$ juta ton pada tahun 2030 (KKP, 2014).

Tambak merupakan salah satu jenis habitat yang dipergunakan sebagai tempat untuk kegiatan budi daya air payau yang berlokasi di daerah pesisir (Suparjo, 2008). Kegiatan budi daya tambak yang terus menerus menyebabkan terjadinya degradasi lingkungan, yang ditandai dengan menurunnya kualitas air (Suparjo, 2008; Butchart et al., 2010; Oha et al., 2017). Kendala lingkungan yang dihadapi dalam kegiatan budi daya diantaranya penataan wilayah atau penataan ruang pengembangan budi daya yang tidak memperhatikan daya dukung lingkungan akibat pengelolaan yang tidak tepat, sehingga menimbulkan permasalahan lingkungan dengan segala aspek komplikasinya dalam kurun waktu yang panjang (Suparjo, 2008).

Daya dukung merupakan konsep dasar yang dikembangkan untuk kegiatan produksi dan pengelolaan sumber daya alam dan lingkungan secara berkelanjutan (Beveridge, 1996). Konsep ini dikembangkan untuk mencegah kerusakan atau degradasi sumber daya alam dan lingkungan. Daya dukung merupakan istilah yang lebih umum untuk karakter lingkungan dan kemampuannya dalam mengakomodasi suatu kegiatan tertentu atau laju suatu kegiatan tanpa dampak yang tidak dapat diterima (GESAMP, 2001).

Banyak metode kebelanjutan yang telah diuraikan sebelumnya oleh beberapa penelitian (Valenti et al.,
2018). Salah satu cara atau metode yang dapat digunakan untuk memantau aktifitas pertambakan adalah dengan interpretasi citra satelit. Melalui analisis citra satelit dengan resolusi spasial tinggi, kegiatan penelitian, analisis, dan pemantauan kawasan pertambakan dan sumber daya lainnya akan lebih mudah, efisien, murah, dan mampu menjangkau area yang luas (Ozesmi \& Bauer (2002); Guixia \& Jiangguo (2006); Biqing (2007); Zhitai et al. (2010). Salah satu jenis citra satelit yang bisa dipergunakan untuk memantau sumber daya di wilayah pesisir adalah citra ALOS (Advanced Land Observing Satelite) yang mempunyai interval spektralnya mirip dengan data Landsat-7 ETM yang umumnya digunakan untuk ekstraksi informasi dasar perairan, perbedaannya adalah pada resolusi spasialnya dan resolusi spektralnya lebih tinggi (Liu et al., 2011; Suwargana, 2014; Motohka et al., 2017; Khati et al, 2018).

Adapun tujuan utama penelitian ini adalah mengidentifikasi kawasan pertambakan melalui pemanfaatan citra satelit ALOS AVNIR-2, kemudian menganalisis daya dukung lahan pertambakan yang terdapat di wilayah pesisir Kabupaten Maros Sulawesi Selatan.

\section{BAHAN DAN METODE}

Analisis data yang dilakukan untuk mengidentifikasi luasan dan sebaran lahan budi daya pesisir adalah interpretasi citra satelit ALOS AVNIR akuisisi 2008. Transformasi citra satelit menggunakan teknik masking (Lyzenga, 1987). Penggunaan teknik masking dalam penelitian ini adalah untuk mengetahui batas antara kawasan pertambakan dengan kawasan daratan non pertambakan, sehingga memudahkan untuk mendelineasi atau memvektorisasi batas-batasnya.

Setelah mengetahui batas dan luasan kawasan pertambakan, maka selanjutnya dilakukan perhitungan daya dukung spasialnya dimana metode yang digunakan adalah Spatial Carrying Ratio atau CCR yang melibatkan dua parameter yaitu, luas lahan pertambakan dan jumlah RTP (Rumah Tangga Perikanan) budi daya. Perhitungan CCR dilakukan pada tiap kecamatan pesisir, dengan harapan bahwa evaluasi pemanfaatan lahan budi daya pesisir bisa lebih spesifik, sehingga regulasi pemanfaatan dan pengelolaan lahan budi daya tambak bisa lebih terarah dan sesuai dengan pola dan struktur ruang dalam rencana tata ruang wilayah daerah.

Sebagai contoh kasus, penelitian mengambil kawasan 


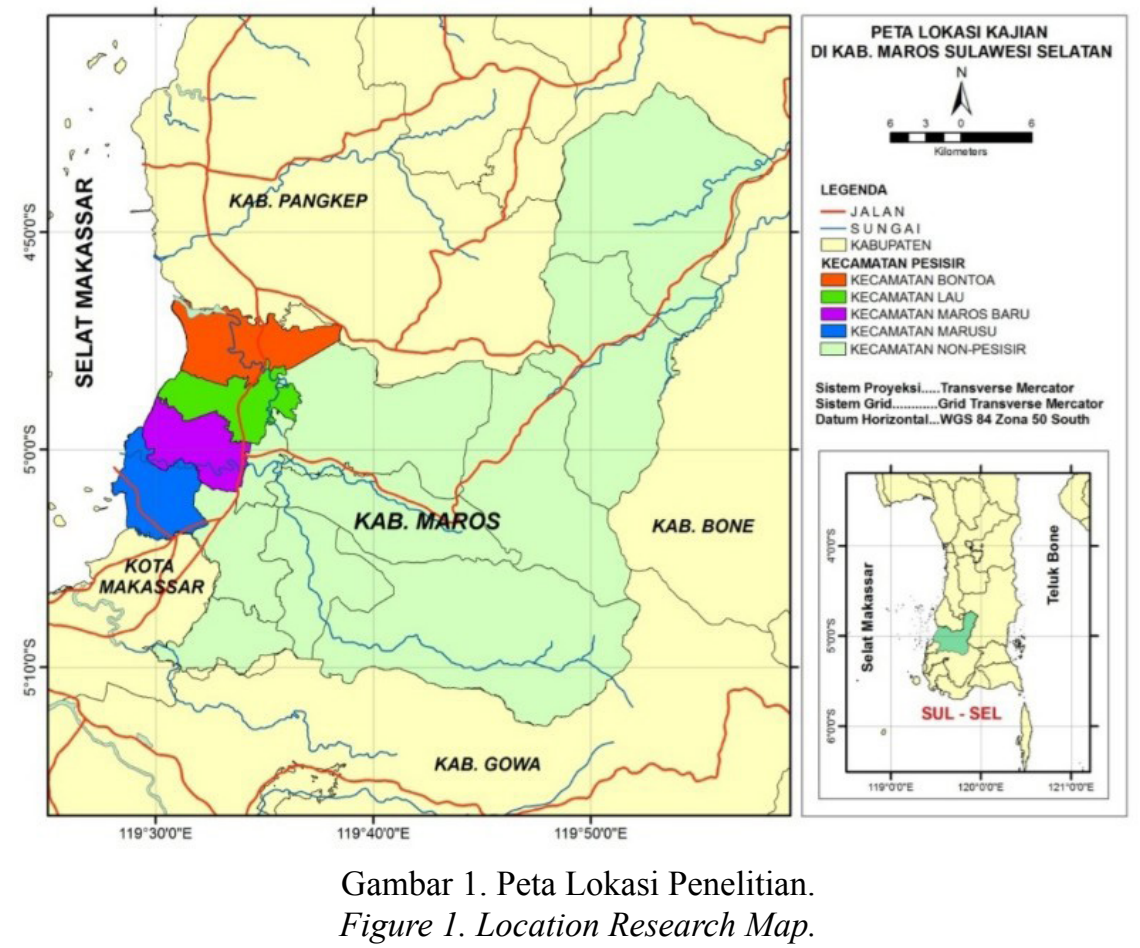

pesisir Kabupaten Maros dengan tahun pengambilan data yang disesuaikan dengan ketersediaan citra satelit ALOS AVNIR-2. Pengukuran CCR dilakukan di empat kecamatan pesisir, agar diperoleh perbandingan pola pemanfaatan dan daya dukung dari masing-masing kecamatan (Gambar 1).

\section{Parameter yang dikaji}

Penelitian ini mencoba mengkaji kemampuan daya dukung lahan terhadap aktifitas masyarakat di kawasan pesisir Kabupaten Maros. Adapun parameter yang dikaji adalah: Luas dan Sebaran Lahan, Sosial Ekonomi Masyarakat Pesisir, dan Kebijakan Pemerintah

\section{Metode Pengumpulan Data}

Teknik pengumpulan data merupakan kombinasi antara interpretasi citra satelit ALOS AVNIR, wawancara/ diskusi, penelusuran literatur, dan survei lapangan.

\section{Analisis Data}

Analisis data yang dilakukan untuk mengidentifikasi luasan dan sebaran sebaran lahan budi daya pesisir adalah interpretasi citra satelit ALOS AVNIR-2 akuisisi 2008. Sensor satelit ALOS yang digunakan untuk mendeteksi tambak adalah sensor AVNIR-2 (Advanced Visible and Near Infrared type 2) dengan resolusi 10 meter karena bisa digunakan untuk menetrasi badan kolom air (JAXA, 2008). AVNIR-2 merupakan pengganti ADEOS (Advanced Earth Observing Satellite) yang diluncurkan pada tahun 2006. Resolusi spasial yang disajikan oleh AVNIR-2 sebesar 10 meter dengan lebar liputan per lembar citra (scene) sebesar $70 \mathrm{~km}$, sedangkan untuk wilayah multispektral memiliki resolusi spasial sebesar 16 meter. AVNIR-2 sering dimanfaatkan untuk mengetahui indeks vegetasi dengan menggunakan band cahaya tampak (visible) dan inframerah dekat (near infrared) (JAXA EORC, 2011).

Karakter ALOS menurut fungsinya, adalah salah satu satelit yang digunakan untuk mengamati permukaan bumi yang dikembangkan dengan tujuan: 1. Menyediakan peta untuk Jepang dan negaranegara lain yang tercakup dalam wilayah Asia-Pasifik (Cartography); 2. Melakukan pengamatan daerah untuk pembangunan berkelanjutan, serta harmonisasi antara lingkungan bumi dengan pembangunan (Regional Observation); 3. Melakukan pemantauan bencana di seluruh dunia (Disaster Monitoring); 4. Survey sumber daya alam (Resources Surveying); 5. Mengembangkan tekhnologi yang diperlukan untuk satelit pengamatan bumi masa depan (Technology Development) (JAXA EORC, 2011).

Sensor AVNIR-2 terdiri dari $4 \mathrm{kanal} / \mathrm{band}$, yaitu: B1 (biru), B2 (hijau), B3 (merah), dan B4 (inframerahdekat), dua diantaranya (sinar biru dan hijau) dapat digunakan untuk identifikasi sebaran terumbu karang, lihat Tabel 1. Kanal biru $(0,42-0,50 \mu \mathrm{m})$ mampu 
bernetrasi hingga kedalaman 25 meter, kanal hijau $(0,52-0,60 \mu \mathrm{m})$ hingga 15 meter dan kanal merah $(0,61$ $0,69 \mu \mathrm{m}$ ) hingga kedalaman 5 meter (Anne et al., 2008). Model interpretasi yang dilakukan adalah dengan memisahkan objek tutupan lahan basah di daratan dengan daratan murni yang bukan lahan basah. Untuk mengidentifikasi lahan budi daya tentunya dipadukan dengan pola dasar lahan budi daya itu sendiri, sehingga antara lahan budi daya tambak, dengan pola tutupan lahan basah alami bisa dibedakan.

Kawasan pertambakan identik dengan kawasan perairan dangkal, sehingga pemanfaatan sensor ANVIR-2 untuk mendeteksi perairan dangkal dinilai cocok, selain karena memiliki resolusi tinggi juga memiliki kemampuan mendeteksi pantulan maksimum dari pada obyek air dengan puncak pantulan air terjadi pada panjang gelombang $\pm 0,45 \mu \mathrm{m}$ (spektral biru), dan pantulan berkurang minimum pada panjang gelombang hingga 0, $65 \mu \mathrm{m}$ (spektrum merah) (Suwargana, 2014).

\section{Koreksi Geometrik}

Pengolahan awal meliputi penggabungan data dan koreksi geometrik (Oo \& Takagi, 2010; Nurandani, 2014). Koreksi geometrik dilakukan dengan metode registrasi (imagery to Imagery). Citra acuannya adalah citra georeferensi yang telah terkoreksi dengan koordinat peta dari Bakosurtanal. Penyamaan posisi ini dimaksudkan agar posisi piksel citra original menjadi sama dengan citra terkoreksi. Jadi proses registrasi citra ke citra disini melibatkan proses georeferensi apabila citra acuannya sudah terkoreksi. Transfomasi koordinat pada citra menggunakan model polynomial (Prasetyo, 2017).

\section{Proses Masking}

Salah satu metode dalam pengolahan citra penginderaan jauh pasif yang paling penting adalah masking. Masking adalah tahap untuk memisahkan antara daerah perairan dan daratan dengan cara memblok nilai digital number (DN) darat dengan nilai nol (Bobsaid \& Jaelani, 2015), sehingga nilai radiansi yang digunakan dalam proses klasifikasi tidak dipengaruhi oleh nilai radiansi dari daratan (Musliadi et al., 2013). Dalam kajian penginderaan jauh kelautan, biasanya masking dilakukan antara nilai piksel untuk daratan dengan nilai lautan yang menjadi daerah kajian (Prasetyo, 2017).

Secara konsep, langkah masking dilakukan dengan membuat citra biner (nilai pixel 0 dan 1) berdasarkan nilai pixel pada band-4 (inframerah dekat). Pada band-4, obyek perairan mempunyai nilai pixel 0 (atau mendekati 0), sedangkan obyek daratan mempunyai nilai pixel yang lebih besar dari 0. Berdasarkan hal tersebut maka dapat dibuat citra biner dimana perairan diberi nilai pixel 1, sedangkan daratan diberi nilai pixel 0 . Citra biner tersebut kemudian diaplikasikan pada masing-masing band, sehingga nilai radiansi daratan tidak ikut diproses dalam pengolahan citra berikutnya (Musliadi et al., 2013).

Dalam penelitian ini, pemisahan antara laut dan daratan (proses masking) dilakukan dengan menggunakan citra ALOS AVNIR-2. Kanal yang digunakan untuk masking adalah kanal inframerah dekat $(0,76-0,89)$ (Tabel 1). Infra merah dekat memiliki karakter dimana apabila terkena perairan dan dipantulkan kembali ke sensor akan menyebabkan warna gelap atau hitam karena nilai yang didapatkan sangat kecil disebabkan oleh hilangnya energi pada panjang gelombang inframerah dekat habis diserap oleh molekul air. Kemudian apabila gelombang inframerah dekat mengenai objek pada daratan masih menyisakan sejumlah energi gelombang elektromagnetik sehingga pada daratan pantulan dari inframerah dekat akan menyebabkan area darat memiliki warna yang cerah (Prasetyo, 2017).

Tabel 1. Kanal inframerah untuk masking

Table 1. Infra red chanel for masking

\begin{tabular}{llll}
\hline Kanal & $\begin{array}{l}\text { Panjang } \\
\text { Gelombang } \\
(\boldsymbol{\mu m})\end{array}$ & $\begin{array}{l}\text { Resolusi } \\
\text { Spasial }(\mathbf{m})\end{array}$ & Karakteristik \\
\hline 1 (biru) & $0,42-0,50$ & 10 & $\begin{array}{l}\text { Penetrasi maksimum pada air } \\
\text { Berfungsi untuk mengindera puncak pantulan vegetasi } \\
\text { Berfungsi untuk membedakan absorpsi klorofil dan tipe } \\
3 \text { (merah) }\end{array}$ \\
$0,52-0,60$ & 10 & 10 & $\begin{array}{l}\text { vegetasi } \\
\text { Untuk menentukan kandungan biomas, tipe vegetasi, } \\
\text { dan pemetaan garis pantai }\end{array}$ \\
4 (merah dekat) & $0,76-0,89$ & 10 &
\end{tabular}

Sumber: NASDA, 2004

JURNAL KELAUTAN NASIONAL, Vol. 13, No 1, April 2018, Hal. 39-51 
Pada proses pemisahan batas darat dan tubuh air memiliki dampak terlihatnya batas yang jelas antara kawasan pertambakan yang identik dengan kawasan berair dengan kawasan daratan di sekitarnya. Teknik dan proses masking dalam penelitian ini menggunakan algoritma Lyzenga, dimana nilai attenuasi kolom perairan dikoreksi secara eksponensial (Lyzenga, 1981). Adapun proses masking sebagai berikut:

1. Melakukan identifikasi nilai piksel yang terindikasi sebagai wilayah perairan dan wilayah darat. Untuk memudahkan proses pengenalan objek, dilakukan perbandingan dua komposit citra. Dalam penelitian ini komposit citra yang digunakan adalah komposit 321 RGB dan komposit 421 RGB. Penggunaan band NIR (band 4) akan lebih menegaskan batas darat dengan tubuh air.

2. Mencari nilai ki/kj melalui training site citra.

$$
\mathrm{ki} / \mathrm{kj}=a+\sqrt{\left(a^{2}+1\right)}
$$

Dimana

$$
a=\frac{(\operatorname{VarTM} 1-\operatorname{VarTM} 2)}{2 * \operatorname{CovarTM} 1 T M 2}
$$

3.Setelah mendapatkan nilai $\mathrm{ki} / \mathrm{kj}$, selanjutnya memasukkan nilai-nilai tersebut ke persamaan 3, yaitu:

\section{If $i 3<=$ landmask then}

$\log (i 1)+(k i / k j) * \log (i 2)$ else null

Dimana,

Land mask = nilai batas darat

$\mathrm{i} 1=$ band 1

$\mathrm{i} 2=$ band 4 (NIR)

$\mathrm{i} 3=$ band 3

4. Proses vektorisasi atau delineasi yaitu merubah data raster menjadi data polygon.

\section{Analisis Carrying Capacity}

Analisis daya dukung spasial (spatial carrying capacity) merupakan integrasi dari analisis spasial dengan analisis carrying capacity ratio. Analisis CCR merupakan suatu alat perencanaan pembangunan yang memberikan gambaran mengenai hubungan antara penduduk, penggunaan lahan, dan lingkungan (McCall, 1995; Riyadi \& Bratakusumah, 2003). Analisis daya dukung telah dipergunakan dalam skala yang luas
(Remus et al., 2012), dapat memberikan informasi yang diperlukan oleh para perencana dalam menilai tingkat kemampuan lahan dalam mendukung segala aktifitas manusia yang ada di wilayah bersangkutan (Riyadi \& Bratakusumah, 2003). Perhitungan carrying capacity melibatkan dua parameter yaitu, potensi lahan yang tersedia termasuk luas lahan, dan jumlah penduduk (Riyadi \& Bratakusumah, 2003). Dalam penelitian ini parameter yang digunakan adalah lahan pertambakan dan RTP budi daya. Perhitungan CCR ini dilakukan pada tiap kecamatan, dengan harapan pola pemanfaatan lahan budi daya pesisir secara spasial bisa lebih spesifik, sehingga regulasi pemanfaatan dan pengelolaan lahan budi daya tambak bisa lebih terarah dan sesuai dengan pola dan struktur ruang dalam rencana tata ruang wilayah daerah.

Adapun langkah-langkah dalam menyusun pembuatan CCR menurut Riyadi \& Bratakusumah (2003) adalah sebagai berikut:

- Mengidentifikasi luas areal yang yang dapat digunakan untuk kegiatan pertanian atau perikanan

- Mengidentifikasi frekuensi panen per hektar per tahun

- Menentukan jumlah keluarga dalam area tersebut

- Menentukan persentase jumlah petani/petambak yang ada dalam area tersebut

- Menghitung kemampuan daya dukung dengan menggunakan analisis CCR.

Persamaan yang digunakan untuk menghitung nilai Spatial Carrying Ratio (CCR) adalah persamaan yang dikembangkan oleh Riyadi \& Bratakusumah (2003) sebagai berikut:

$C C R=(A * r) / H * h * F 4$

Dimana:

$\mathrm{A}=$ Jumlah total area yang dapat digunakan untuk kegiatan pertanian atau perikanan budi daya

$\mathrm{r}=$ Frekuensi panen per hektar per tahun

$\mathrm{H}=$ Jumlah RTP budi daya tambak

$\mathrm{h}=$ persentase jumlah penduduk yang tinggal

$\mathrm{F}=$ ukuran lahan perikanan budi daya rata-rata yang dimiliki oleh petambak

Asumsi umum yang digunakan untuk menginterpretasi hasil perhitungan adalah (Riyadi \& Bratakusumah, 2003):

-. CCR $>1$, berarti bahwa dilihat berdasarkan kuantitas lahannya, suatu wilayah masih memiliki kemampuan untuk mendukung kebutuhan pokok penduduk dan masih mampu menerima tambahan penduduk. 


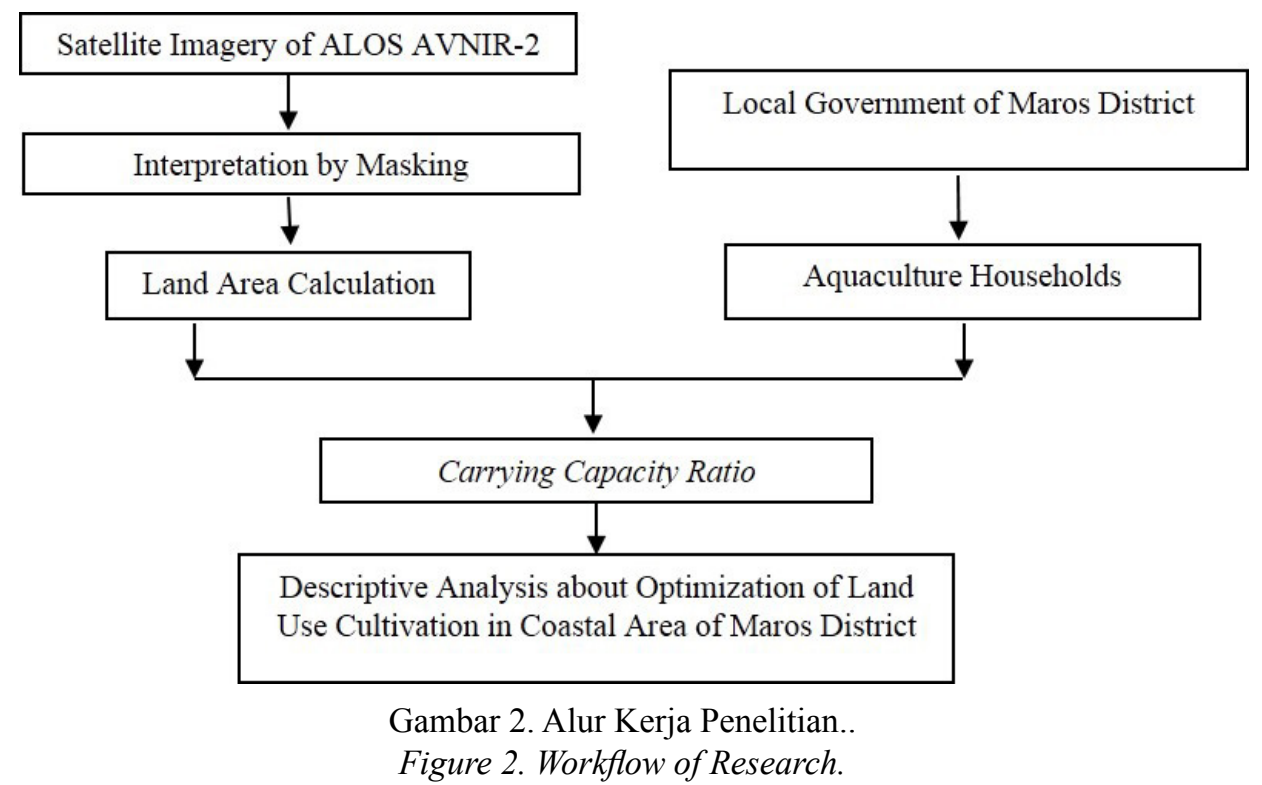

Pembangunan masih dimungkinkan bersifat ekspansif dan eksploratif lahan.

-. CCR $<1$, berarti bahwa berdasarkan jumlah lahan yang ada, di wilayah tersebut sudah tidak mungkin dilakukan pembangunan bersifat ekspansif dan eksploratif lahan. Kemampuan untuk memenuhi kebutuhan pokok penduduk menjadi berkurang, sehingga perlu dilakukan program peningkatan produktifitas, intensifikasi, dan ekstensifikasi melalui perbaikan teknologi atau menekan pertumbuhan penduduk.

-. CCR $=1$, berarti bahwa daerah tersebut masih memiliki keseimbangan antara kemampuan lahan dan jumlah penduduk. Pemenuhan kebutuhan pokok masih dapat diatasi atau sumber daya wilayah masih mampu memenuhi kebutuhan masyarakatnya.

\section{HASIL DAN PEMBAHASAN}

\section{Interpretasi Citra}

Composit 321 RGB merupakan warna alami (True Colour) dari suatu objek di muka bumi. Menampilkan pewarnaan true colour dalam suatu interpretasi citra satelit sangatlah penting, khususnya untuk wilayah yang tidak dikenal. Dengan menampilkan pewarnaan alami, maka objek yang terlihat akan mudah dikenali karena telah familiar di mata (Gambar 3A).

Penggunaan band 4 (Near Infra Red/NIR) pada komposit 421 RGB berguna untuk menampilkan batas tegas antara darat dan air sehingga memudahkan untuk mengidentifikasi nilai-nilai piksel yang terindikasi
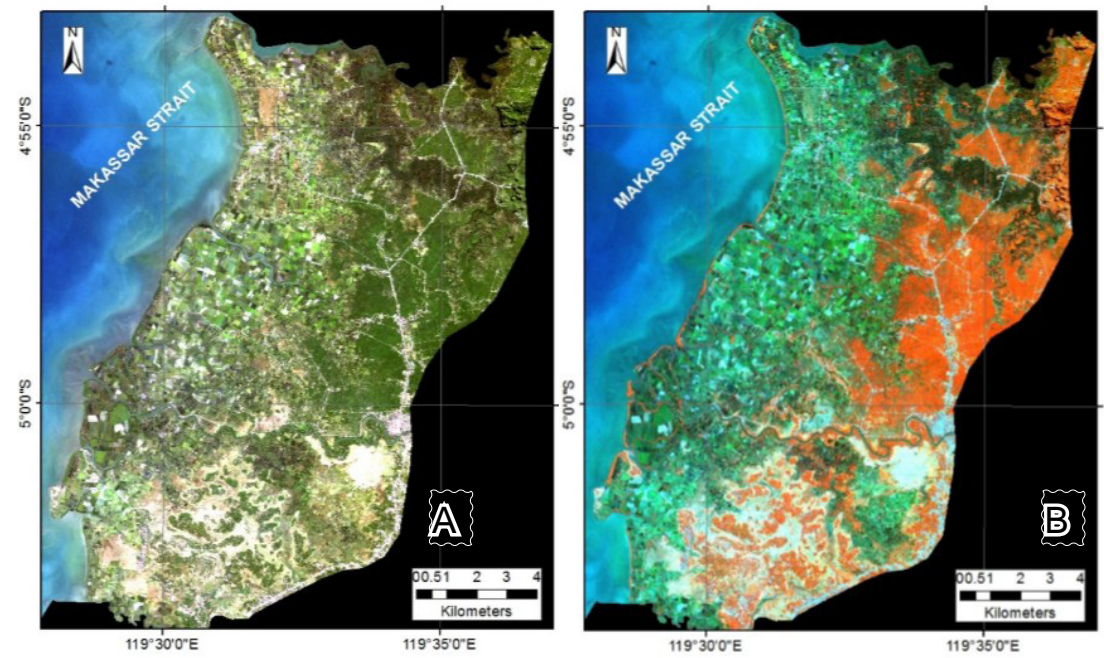

Gambar 3. Hasil analisis citra satelit dengan teknik masking; A) Komposit band 321 RGB;

B) Komposit band 421 RGB.

Figure 3. Result of satellite imagery analysis using masking technique; A) Composite band 321 RGB;

B) Composite band 421 GB..

JURNAL KELAUTAN NASIONAL, Vol. 13, No 1, April 2018, Hal. 39-51 

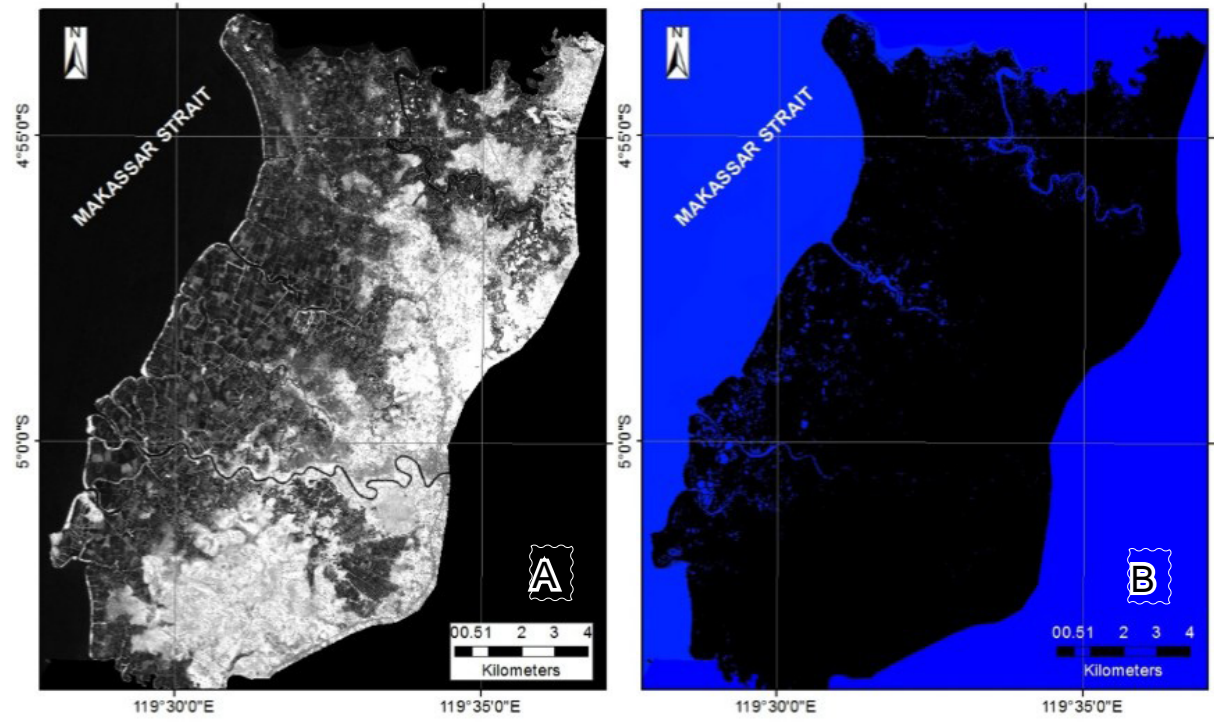

Gambar 4. A) Warna tunggal band 4 (near infra red); B) Hasil pemisahan batas darat dan air.

Figure 4. A) Single color band 4 (near infra red); B) The result of separation between land and water boundaries.

sebagai air atau tubuh air dan bukan air. Komposit 421 juga bisa memberikan pewarnaan kontras terhadap vegetasi darat, ruang terbuka tanpa vegetasi, dengan area tangkapan air seperti rawa, tambak, dan sawah (Gambar 3B).

Gambar 4A menunjukkan band 4 atau near infra red (NIR) pada gelombang 0,76-0,89 $\mu \mathrm{m}$. Karakter band ini adalah Untuk menentukan kandungan biomas, tipe vegetasi, dan pemetaan garis pantai (NASDA, 2004). Pada band 4 citra ALOS, terlihat batas yang sangat tegas antara daratan dan lautan. Hal tersebut disebabkan karena pada gelombang NIR, cahaya terserap sempurna oleh perairan, sehingga menampilkan pewarnaan yang gelap atau 0. Pada saat mengidentifikasi nilai-nilai piksel yang diindikasikan sebagai darat atau bukan air, tampilan warna tunggal band 4 akan sangat membantu proses interpretasi (Gambar 5A).

Gambar 5B menampilkan citra hasil pemisahan antara darat dan air dengan menggunakan persamaan 1. Hanya saja, pada gambar tersebut, nilai batas rata-rata yang sesuai dengan objek bukan air belum dimasukkan dalam model. Pada kondisi tersebut, area tambak belum teridentifikasi, yang terlihat hanyalah batas tegas antara daratan dan lautan atau sungai. Citra tersebut sangat
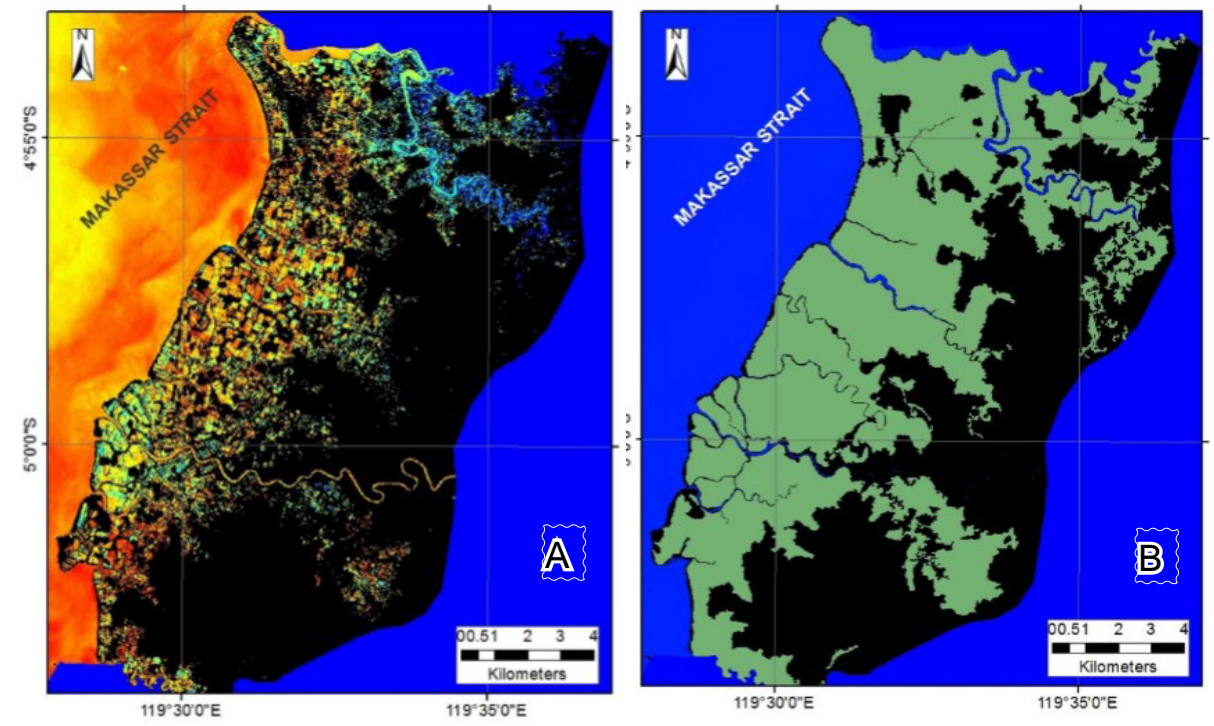

Gambar 5. A) Hasil pemisahan batas darat dan air setelah proses input masking; B) Hasil proses vektorisasi.

Figure 5. A) The result of separation between land and water boundaries after input masking process; B) The result of the vectorization process. 
cocok untuk pemetaan garis pantai.

Gambar 5A menunjukkan hasil akhir dari proses masking, dimana batas antara kawasan yang diprediksi tambak atau kawasan perairan di darat dapat terdefinisi dengan jelas. Perlu interpretasi lebih lanjut, dimana karakter objek tidak hanya ditentukan oleh pewarnaan saja, akan tetapi juga dari struktur dan pola objek. Perlu dicatat pula bahwa kawasan tambak juga tidak selamanya tertutupi oleh kolom air, tetapi pada beberapa waktu tertentu bisa saja kering, sehingga bisa saja pada waktu scanning citra oleh satelit, kondisi atau objek tambak akan terbaca sebagai darat. Olehnya itu, pada proses vektorisasi (Gambar 5B), digitasi overlay atau membandingkan objek dengan komposit 321 RGB dan 421 RGB tetap harus dilakukan.

\section{Luasan dan Sebaran Kawasan Pertambakan}

Berdasarkan hasil perhitungan luasan tambak di wilayah pesisir Kabupaten Maros berdasarkan interpretasi data citra satelit ALOS AVNIR-2 tahun 2008 diperoleh luasan tambak sekitar 9.621,60 Ha (Gambar 6 dan Tabel 2). Sebaran lahan tambak mendominasi fungsi pemanfaatan lahan di empat kecamatan pesisir Kabupaten Maros. Hal tersebut mengindikasikan besarnya kebutuhan dan ketergantungan masyarakat terhadap produksi lahan tambak pada kawasan tersebut. Sebagai salah satu sumber pangan utama, kawasan pertambakan juga menjadi barometer pendapatan daerah Kabupaten Maros. Pemanfaatan lahan pertambakan terlihat maksimal pada wilayah Kecamatan Bontoa, dimana dua pertiga wilayahnya dimanfaatkan sebagai lahan pertambakan, sedangkan Kecamatan Lau dengan garis pantai terpendek menjadi terkecil dalam memanfaatkan lahan sebagai tambak.

Kecamatan Bontoa selain menjadi kawasan pertambakan terluas, konsentrasi masyarakat untuk bermukim di wilayah kecamatan tersebut besar. Hal tersebut disebabkan oleh dekatnya infrastruktur jalan dan pasar, sehingga masyarakat lebih menyenangi untuk bermukim pada wilayah tersebut. Kecamatan Bontoa yang berdekatan dengan kawasan karst Maros dimana sumber air tawar dan irigasinya relatif besar, menjadikan kecamatan ini juga banyak dimanfaatkan sebagai lahan persawahan yaitu sebesar 5.246 hektar (BPS Kabupaten Maros, 2009). Pemanfaatan lahan yang beragam tersebut mengindikasikan besarnya nilai ekonomi dan beragamnya jenis mata pencaharian masyarakat di wilayah tersebut.

Ketiga kecamatan selain Kecamatan Bontoa, relatif memiliki karakteristik pemanfaatan lahan yang sama, hanya saja Kecamatan Marusu merupakan kecamatan yang relatif terisolir karena letak kawasan pertambakan berada pada delta Sungai Kuri Lompo, sehingga menyebabkan pemanfaatan lahannya didominasi tambak-tambak yang luas, sedangkan pemiliknya kebanyakan bermukim di luar kecamatan tersebut.

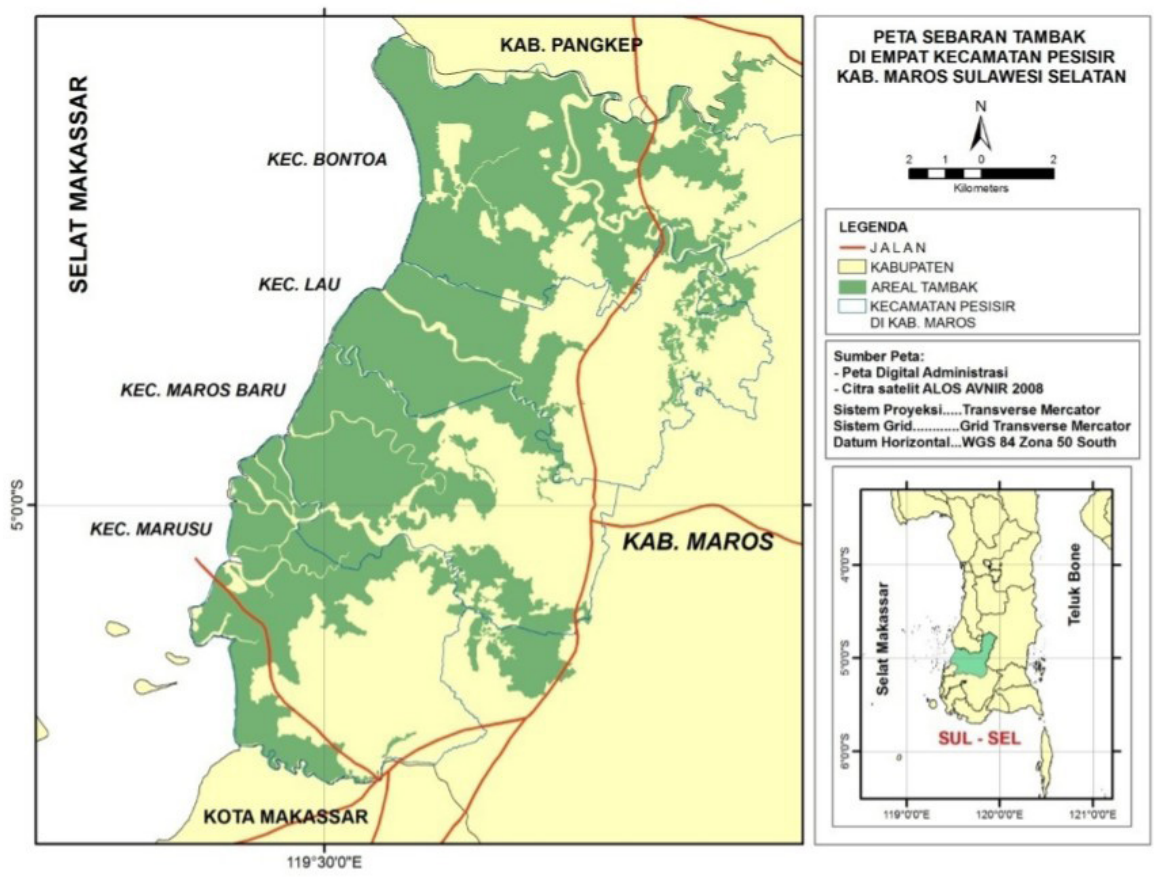

Gambar 6. Sebaran tambak di kawasan pesisir Kabupaten Maros.

Figure 6. The distribution of fish ponds in the coastal area of Maros Regency. 
Tabel 2. Hasil interpretasi citra satelit ALOS AVNIR luas lahan budidaya tambak

Table 2. Result of ALOS AVNIR satellite image interpretation of fish pond farming area

\begin{tabular}{lll}
\hline No & Kecamatan & Luas Tambak (ha) \\
\hline 1 & Bontoa & $2.209,29$ \\
2 & Lau & $2.732,60$ \\
3 & Maros Baru & $1.627,71$ \\
4 & Marusu & $3.052,00$ \\
\hline & Total & $9.621,60$
\end{tabular}

Sumber: Hasil Analisis (2017)

Sebagai wilayah yang terletak di kawasan delta/ muara, vegetasi mangrove juga mendominasi wilayah tersebut, hanya saja, ekspansi lahan tambak yang tidak terkontrol, menjadikan ekosistem mangrove pada wilayah ini semakin terdegradasi.

\section{Produksi Tambak di Kabupaten Maros}

Jenis komoditi perikanan yang dibudidayakan di kawasan tambak seluas 9.621,60 hektar di Kabupaten Maros adalah udang dan bandeng. Produksi terbesar dari hasil perikanan tambak adalah jenis ikan bandeng mencapai $2.740,12$ ton yang relatif banyak diproduksi pada Kecamatan Bontoa mencapai 1.254,01 ton dan Kecamatan Marusu sebesar 1.285,08 ton. Potensi pengembangan perikanan darat cukup potensial dengan bentang pantai yang cukup panjang pada empat kecamatan kawasan pesisir yaitu Kecamatan Maros Baru, Marusu, Lau, dan Bontoa (Tabel 3). Dari jumlah total produksi perikanan tambak tersebut, wilayah Kecamatan Bontoa memiliki persentase terbanyak, yakni sebesar 30,74\%, kemudian Kecamatan Marusu dan Maros Baru, masing-masing 27,30\% dan 23,30\%.

\section{Daya Dukung Lahan (Carrying Capacity Ratio)}

Secara umum, hasil kajian daya dukung lahan tambak di pesisir Kabupaten Maros menunjukkan nilai rasio sebesar 2,73 (CCR $>1)$ yang berarti bahwa berdasarkan kuantitas lahan pertambakan di empat kecamatan pesisir Kabupaten Maros, kawasan tersebut masih memiliki kemampuan (daya dukung) yang cukup tinggi terhadap aktifitas pembangunan daerah Kabupaten Maros. Dengan nilai daya dukung sebesar 2,73, kawasan pesisir Maros masih memiliki kemampuan untuk mendukung aktifitas-aktifitas penduduknya, khususnya pada sektor perikanan budi daya air payau.

Untuk masing-masing kecamatan, nilai CCR (Carrying Capacity Ratio) adalah sebagai berikut: Kecamatan Marusu memperoleh nilai CCR tertinggi yaitu 4,06; nilai CCR tertinggi kedua oleh Kecamatan Lau dengan nilai CCR 3,84; nilai CCR tertinggi ketiga oleh Kecamatan Maros Baru sebesar 3,79; dan nilai CCR yang terkecil oleh Kecamatan Bontoa dengan nilai CCR 1,73 (Tabel 4).

Secara garis besar, dengan rata-rata luas penggunaan tambak yang $<2$ hektar per petaknya, nilai CCR kawasan tambak secara keseluruhan di Kabupaten Maros masih di atas $1(\mathrm{CCR}>1)$. Ini berarti bahwa, kawasan pertambakan di Kabupaten Maros secara kuantitas masih menunjukkan kemampuan lahan yang ideal untuk upaya peningkatan produksi komoditas perikanan secara berkelanjutan.

Berdasarkan asumsi, kebutuhan ideal lahan tambak oleh tiap RTP adalah 2 hektar, artinya bahwa setiap petani tambak memiliki kelebihan lahan rata-rata 0,73 hektar. Kelebihan lahan tersebut dapat terlihat dari besarnya produksi budi daya sebesar rata-rata 1,47 ton/ RTP/tahun (perkiraan kasar: seandainya $1 \mathrm{~kg}$ bandeng $=20.000$, maka $1.470 \mathrm{~kg}=29.400 .000$. Namun ditinjau melalui kemampuan lahan budi daya melalui rasio mangrove yang tersedia, maka pengembangan lahan budi daya yang bersifat ekspansif dan eksploratif lahan sudah tidak memungkinkan. Berdasarkan kajian pengembangan budi daya payau dengan konsep

Tabel 3. Luas Areal dan jumlah produksi usaha perikanan tambak Kabupaten Maros Table 3. Area and total production of fish pon in Maros Regency

\begin{tabular}{|c|c|c|c|c|c|}
\hline \multirow[t]{2}{*}{ No } & \multirow[t]{2}{*}{ Kecamatan } & \multirow{2}{*}{$\begin{array}{l}\text { Luas Areal } \\
\text { Tambak (Ha) }\end{array}$} & \multicolumn{2}{|c|}{ Jenis Produksi (ton) } & \multirow[t]{2}{*}{ Jumlah } \\
\hline & & & Udang & Ikan & \\
\hline 1 & Maros Baru & $2.209,29$ & 335,01 & 917,04 & $1.252,05$ \\
\hline 2 & Marusu & $2.732,60$ & 573,04 & 1.285 .08 & 573,04 \\
\hline 3 & Lau & $1.627,71$ & 275,03 & 569,07 & 844,10 \\
\hline \multirow[t]{2}{*}{4} & Bontoa & $3.052,00$ & 361,00 & $1.254,01$ & $1.615,01$ \\
\hline & Jumlah Total & $9.621,60$ & $1.544,08$ & $2.740,12$ & $4.284,20$ \\
\hline
\end{tabular}

Daya Dukung Spasial Kawasan Pertambakan Melalui Interpretasi Citra Satelit Alos Avnir-2 Studi Kasus Kabupaten Maros Sulawesi Selatan 
Tabel 4. Hasil Perhitungan Carrying Capacity Ratio (CCR)

Table 4. Carrying Capacity Ratio Calculation Result (CCR)

\begin{tabular}{|c|c|c|c|c|c|}
\hline $\begin{array}{l}\text { Nama } \\
\text { Kecamatan } \\
\text { di Kabupaten } \\
\text { Maros }\end{array}$ & $\begin{array}{l}\text { Luas Tambak } \\
\text { (Ha) }\end{array}$ & $\begin{array}{l}\text { RTP }(\text { KK) di } \\
\text { empat } \\
\text { kecamatan } \\
\text { pesisir } \\
\text { (BPS, 2010) }\end{array}$ & $\begin{array}{l}((\text { luas lahan/2)x3 } \\
\text { panen })+(\text { luas } \\
\text { lahan/2)x2 panen)) }\end{array}$ & $\begin{array}{l}\text { CCR dari total } \\
\text { RTP Budidaya } \\
\text { (KK) terhadap } \\
\text { luas tambak } \\
\text { yang ada }\end{array}$ & $\begin{array}{l}\text { CCR dari total } \\
\text { RTP Budidaya } \\
\text { (KK) terhadap } \\
\text { luas tambak pada } \\
\text { skala kecil }\end{array}$ \\
\hline Maros Baru & $2.209,29$ & 970 & $5.523,23$ & 5,69 & 3,79 \\
\hline Marusu & $2.732,60$ & 1.120 & $6.831,50$ & 6,10 & 4,06 \\
\hline Lau & $1.627,71$ & 706 & $4.069,28$ & 5,76 & 3,84 \\
\hline Bontoa & $3.052,00$ & 2.940 & $7.630,00$ & 2,60 & 1,73 \\
\hline Total & $9.621,60$ & $5.736,00$ & $24.054,00$ & 4,19 & 2,79 \\
\hline
\end{tabular}

silvofishery nilai daya dukung kawasan budi daya sebesar 0,55 yang artinya bahwa selain pengembangan kawasan budi daya yang ekspansif dan eksploratif sudah tidak memungkinkan, jumlah RTP sudah melebihi kapasitas untuk mampu memaksimalkan hasil produksi. Strategi: perlu dilakukan peningkatan produktivitas, intensifikasi, dan ekstensifikasi melalui perbaikan teknologi atau menekan petumbuhan penduduk.

Kecamatan Bontoa dengan nilai CCR terendah, mengindikasikan bahwa pemanfaatan lahan tambak pada wilayah tersebut sudah maksimal dan mendekati nilai kritis. Hal tersebut patut mendapatkan perhatian serius terutama oleh pemangku kebijakan, utamanya dalam hal pengelolaan tata ruang. Bahwa ruang-ruang yang layak menjadi tambak, permukiman, dan sawah, sudah memiliki batas-batas spasial yang jelas, sehingga kedepannya degradasi lingkungan yang semakin besar dapat dihindari. Strategi pengelolaan yang tepat pada kecamatan ini adalah dengan melakukan upaya peningkatan produktivitas, intensifikasi, dan ekstensifikasi melalui perbaikan teknologi atau menekan petumbuhan penduduk.

Kecamatan Lau dan Maros Baru memiliki nilai CCR yang relatif sama. Hal tersebut berarti bahwa fungsi lahan dan penggunanya memiliki karakteristik geografi dan demografi yang sama. Kondisi wilayah yang agak jauh dari kota dan infrastruktur utama, menjadikan wilayah ini cukup ideal untuk menjadi kawasan pertambakan. Nilai CCR $>3$ mengindikasikan bahwa kawasan pertambakan pada wilayah tersebut masih mampu menopang pertumbuhan ekonomi masyarakat pesisir dan daerah Maros secara umum. Dengan nilai daya dukung lahan yang masih ideal, penambahan jumlah penduduk pada batas tertentu masih dimungkinkan. Luas lahan relatif masih mampu mendukung aktifitas dan produktifitas yang maksimal untuk pembangunan daerah.

Kecamatan Marusu sebagai wilayah yang paling
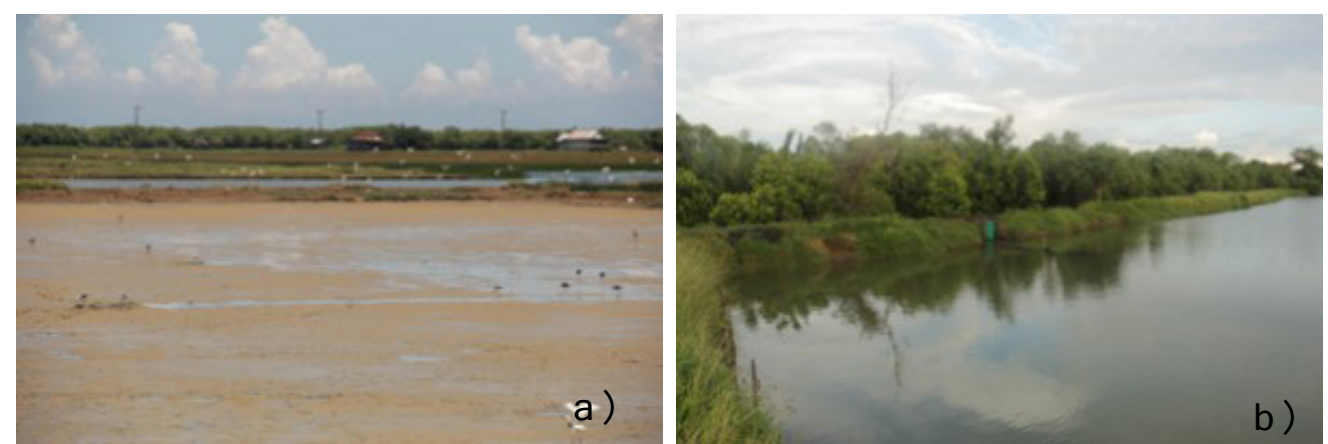

Gambar 7. Kondisi tambak di Kecamatan Bontoa, dimana fungsi lahan beragam, seperti permukiman, sawah, dan tambak (a), Kondisi tambak di Kecamatan Marusu, dimana vegetasi mangrove masih mendominasi di sepanjang pematang tambak dan fungsi lahannya tidak beragam.

Figure 6. The condition of fish ponds in Bontoa sub-district, where the function of the land are varies, such as settlements, rice fields, and fish ponds (a), fish pond conditions in Marusu subdistrict, where mangrove vegetation still dominates along pond embankment and land function is non diverse. 
terisolir, dengan posisi geografis terletak di muara/ delta sungai Kuri Lompo, dimana untuk menuju ke wilayah tersebut masih harus menggunakan perahu menyusuri sungai. Kemudian pertumbuhan mangrove alami masih besar, menjadikan wilayah ini memiliki nilai CCR yang cukup besar. Kondisi ini merupakan potensi sumber daya yang apabila dapat dikelola dan dimanfaatkan dengan lebih arif, akan menjadi sumber pendapatan ekonomi yang luar biasa besar. Selain sebagai potensi sumber daya yang besar, kawasan ini juga rentan terhadap perubahan lingkungan akibat aktifitas masyarakat. Sebagai wilayah kecamatan yang memiliki banyak muara sungai, tentunya penggunaan lahan dan aktifitas masyarakat di huluakan menjadi salah satu faktor peubah lingkungan pada wilayah tersebut Kecamatan Marusu juga merupakan kecamatan yang berbatasan langsung dengan Kecamatan Biringkanaya Kota Makassar, dimana Kecamatan Biringkanaya juga merupakan kawasan industri Makassar, yang tentunya aktifitas industri kaitannya dengan lingkungan sekitar menjadi sangat penting. Koordinasi yang dituangkan dalam bentuk regulasi bersama antar Kota Makassar dan Kabupaten Maros mutlak ada dan harus diimplementasikan secepatnya, untuk menghindari pengaruh atau dampak lingkungan yang diakibatkan oleh keberadaan aktifitas-aktifitas industri di Kota Makassar.

Selain penambahan jumlah penduduk yang masih dimungkinkan pada ketiga kecamatan terakhir, perluasan lahan tambak juga masih memungkinkan, akan tetapi strategi pengelolaannya harus berkelanjutan, yaitu dengan menambah luasan kawasan mangrove (green belt) di sepanjang pantai terluar atau melakukan pola tambak silvofishery.

\section{KESIMPULAN DAN SARAN}

Berdasarkan hasil kajian daya dukung lahan tambak di pesisir Kabupaten Maros menunjukkan nilai rasio sebesar 2,79 atau nilai $\mathrm{CCR}>1$ yang berarti bahwa berdasarkan kuantitas lahan pertambakan di kawasan pesisir Kabupaten Maros masih memiliki kemampuan lahan yang relatif cukup terhadap aktifitas masyarakat pesisir di Kabupaten Maros, khususnya pada sektor perikanan budi daya air payau.

Dari keempat kecamatan pesisir di Kabupaten Maros, nilai CCR terendah diperoleh Kecamatan Bontoa $(1,73)$, Kecamatan Maros Baru $(3,79)$, Kecamatan Lau $(3,84)$, dan Kecamatan Marusu $(4,06)$.
Nilai CCR Kecamatan Bontoa menunjukkan nilai rasio yang terendah yang berarti bahwa lahan tambak yang tersedia sudah mendekati nilai kritis dan hampir tidak mampu mendukung sepenuhnya aktifitas masyarakatnya. Strategi pengelolaan yang tepat pada kecamatan ini adalah dengan melakukan upaya peningkatan produktivitas, intensifikasi, dan ekstensifikasi melalui perbaikan teknologi atau menekan petumbuhan penduduk. Sedangkan Kecamatan Lau $(3,84)$, Kecamatan Maros Baru $(3,79)$, dan Kecamatan Marusu $(4,06)$ relatif masih mampu mendukung aktifitas dan produktifitas yang maksimal untuk pembangunan daerah. Ketiga kecamatan tersebut masih bisa mendapatkan penambahan penduduk atau dilakukan ekspansi lahan dengan strategi pengelolaan berkelanjutan, yaitu dengan menambah luasan kawasan mangrove (green belt) di sepanjang pantai terluar atau melakukan pola tambak silvofishery.

\section{UCAPAN TERIMA KASIH}

Penelitian ini didanai oleh DIPA Puslitbang Sumber Daya Laut dan Pesisir Balitbang Kelautan dan Perikanan Kementerian Kelautan dan Perikanan Tahun Anggaran 2012. Ucapan terima kasih atas bantuan arahan dan bimbingan penelitian dari Bapak Prof. Dr. Dietrich G. Bengen, DEA dan Kepala Pusat Penelitian dan Pengembangan Sumber Daya Laut dan Pesisir.

\section{DAFTAR PUSTAKA}

Anne, K.S.M, Sulma, S. \& Indarto, D. (2008). Aplikasi Alos Untuk Pemetaan Terumbu Karang Di Perairan Utara Bali. Potensi dan Pemanfaatan Data Satelit Inderaja ALOS, SPOT, dan Landsat. ISBN: 978-979-1458-177. Lapan.

Beveridge, M.C.M. (1996). Carryng Capasity Models and Environment Impact. FAO Fish. Tech. Pap.255: 1-131.

Biqing, H. (2007). Analysis of landscape structural features of Zhuzhou urban Greenland based on fine-resolutioned satellite imagery. Scientia Silvae Sinicae. 2007; 43(3), 127-132. (In Chinese with English abstract).

Bobsaid, M.W. \& Jaelani, L.M. (2015). Studi Pemetaan Batimetri Perairan Dangkal Menggunakan Citra Satelit Landsat 8 dan Sentinel-2A (Studi Kasus: Perairan Pulau Poteran dan Gili Iyang, Madura). JURNAL TEKNIK ITS Vol. 4, No. 1, (2015) ISSN: 2337-3539 (2301-9271 Print).

BPS Kabupaten Maros Tahun 2009 dan 2010.

Butchart, Stuart H.M., Walpole, Matt, Collen, Ben, van Strien, Arco, Scharlemann, Jörn P.W., Almond, Rosamunde E.A., Baillie, Jonathan E.M., Bomhard, Bastian, Brown, Claire, Bruno, John, Carpenter, Kent E., Carr, Geneviève M., Chanson, Janice, Chenery, Anna M., Csirke, Jorge, Davidson, Nick C., Dentener, 
Frank, Foster, Matt, Galli, Alessandro, Galloway, James N., Genovesi, Piero, Gregory, Richard D., Hockings, Marc, Kapos, Valerie, Lamarque, Jean-Francois, Leverington, Fiona, Loh, Jonathan, McGeoch, Melodie A., McRae, Louise, Minasyan, Anahit, Hernández Morcillo, Monica, Oldfield, Thomasina E.E., Pauly, Daniel, Quader, Suhel, Revenga, Carmen, Sauer, John R., Skolnik, Benjamin, Spear, Dian, Stanwell-Smith, Damon, Stuart, Simon N., Symes, Andy, Tierney, Megan, Tyrrell, Tristan D., Vié, Jean-Christophe, \& Watson, Reg. (2010). Global biodiversity: indicators of recent declines. Science 328 (5982), 1164-1168.

GESAMP (IMO/FAO/UNESCO-IOC/WMO/ WHO/IAEA/ UN/UNEP Joint Group of Experts on the Scientific Aspects of Marine Environmental Protection). 2001. Planning and Management for Sustainable Coastal Aquaculture Development. Food and Agriculture Organization of the United Nations, Rome. http:// www.fao.org/docrep/005/y1818e/y1818e00.htm. [17 Juni 2009].

Gusmawati N, Soulard B, Folcher NS, Proisy C, Mustafa A, Gendre RL, Laugier T. \&Lemonnier H. (2017). Surveying shrimp aquaculture pond activity using multitemporal VHSR satellite imagerys - case study from the Perancak estuary, Bali, Indonesia. Marine Pollution Bulletin (2017). Elsevier. https://doi. org/10.1016/ j.marpolbul.2017.03.059

JAXA. (2008). ALOS data users handbook: revision $C$. Japan Aerospace Exploration Agency.

JAXA EORC. (2011). About ALOS. http://www.eorc.jaxa. jp/ALOS/en/about/about_index.htm. [08 Oktober 2012]

Kementerian Kelautan dan Perikanan (KKP). (2014). Kelautan dan Perikanan dalam Angka 2014. Pusat Data, Statistik dan Informasi. (340 pp.).

Khati U, Kumar V, Bandyopadhyay D, Musthafa M. \& Singh G. (2018). Identification of forest cutting in managed forest of Haldwani, India using ALOS-2/PALSAR-2 SAR data. Journal of Environmental Management Xxx (2018) 1e10. Elsevier.

Kusumastanto, T. _. Pemberdayaan Sumber daya Kelautan, Perikanan, dan Perhubungan Laut dalam Abad XXI. Pusat Kajian Sumber daya Pesisir dan Lautan. Institut Pertanian Bogor. Bogor.

Liu, Q., Liu, G., Huang, C., Xie, C. \& Shi, L. (2011). Using ALOS High Spatial Resolution Imagery to Detect Vegetation Patches. 2011 3rd International Conference on Environmental Science and Information Application Technology (ESIAT 2011). Procedia Environmental Sciences 10 (2011) 896 901.

Lyzenga, R.D. (1987). Shallow Water Bathymetry Using Combined Lidar and Passive Multiaoectral Scanner Data. Int Journal Remote Sensing Vol 6.

McCall, M.K. (1995). Penaksiran sumber daya dalam perencanaan wilayah, dalam perencanaan sebagai suatu dialog. LAN-DSE, Jakarta.
Motohka, T., Kankaku, Y. \& Suzuki, S. (2017). Advanced land observing Satellite-2 (ALOS-2) and its follow-on L-band SAR mission. In: 2017 IEEE Radar Conference (RadarConf), Seattle, WA, pp. 0953e0956. https://doi. org/10.1109/ RADAR.2017.7944341.

Musliadi, Amran M.A. \& Yasir, I. (2013). Karakteristik Reflektansi Spektral Citra Landsat Etm+ Pada Kawasan Budi daya Rumput Laut Di Kabupaten Bantaeng.

NASDA (National Space Development Agency of Japan). (2004). ALOS: Advanced Land Observing Satellite, Satellite and Program, Japan, 2004.

Nurandani, P. (2014). Pengolahan Data Penginderaan Jauh Untuk Pemetaan Total Suspended Solid (Tss) Di Danau Rawa Pening Provinsi Jawa Tengah. Seminar Nasional Penginderaan Jauh 2014.

Oha RRY, Friess DA. \& Brown BM. (2017). The role of surface elevation in the rehabilitation of abandoned aquaculture ponds to mangrove forests, Sulawesi, Indonesia. Ecological Engineering 100 (2017) 325334. Elsevier.

Oo, K. S. \& Takagi, M. (2010). Land cover classification for forest management using ALOS AVNIR-2 imagerys. International Symposium on Social Management Systems 2010. Kochi, Japan, paper \#SMS10-170.

Ozesmi, S.L. \& Bauer, M.E. (2002). Satellite remote sensing of wetlands. Wetlands Ecol. Manage. 10, 381-402.

Pemkab Maros. (2012). Potensi Perikanan Kabupaten Maros. http://maroskab.go.id/ statis-24-perikanan. html (diakses tanggal 8 Oktober 2012.

Prasetyo, B.A. (2017). Metode Masking Citra Landsat 8 Antara Laut dengan Darat. http://www.goldenchoco. web.id/archives/blog/1064/read.html.

Pusat Data, Statistik, dan Informasi KKP. (2015). Kelautan dan Perikanan dalam Angka tahun 2015.

Remus E, Tecon, R., Kowalchuk, GA. \& Leveau, JHJ. (2012). Variation in local carrying capacity and the individual fate of bacterial colonizers in the phyllosphere. ISME J. 6, 756e765. https://doi.org/10.1038/ismej.2011.209.

Riyadi \& Bratakusumah, D.S. (2003). Perencanaan pembangunan daerah. Strategi menggali potensi dalam mewujudkan otonomi daerah. PT. Gramedia Pustaka Utama, Jakarta.

Suparjo, M.N. (2008). Environmental Carrying Capacity of Water Fishpond's Mororejo Village Kendal Regency. Jurnal Saintek Perikanan Vol. 4, No. 1, 2008: 50 - 55

Suwargana, N. (2014). Analisis Citra Alos Avnir-2 Untuk Pemetaan Terumbu Karang (Studi Kasus: Banyuputih, Kabupaten Situbondo). Deteksi Parameter Geobiofisik dan Diseminasi Penginderaan Jauh. Seminar Nasional Penginderaan Jauh 2014.

, Passive Remote Sensing Technique for Mapping of Water Depth and Bottom Feature, Applied Optic, 1987.

Tran N, Rodriguez UP, Chana CY, Phillipsa MJ, Mohana CV, Henrikssona PJG, Koeshendrajana S , Suria S, \& Hall S. (2017). Indonesian aquaculture futures: An analysis of fish supply and demand in Indonesia 
to 2030 and role of aquaculture using the Asia Fish model. Marine Policy 79 (2017) 25-32. Elsevier.

Valenti WC, Kimpara JM, Pretoc DL, \& Valenti PM. (2018). Indicators of sustainability to assess aquaculture systems. Ecological Indicators 88 (2018) 402-413. Elsevier.

Zhitai, W., Zhijie, W., \& Yu, B. (2010). Urban Greenland landscape structure in Tongren based on Quickbird. Journal of Northwest Forestry University. 2010; 25(1), 166-170. (In Chinese with English abstract). 